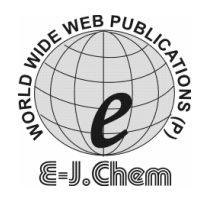

\title{
Crystalline and Molecular Structure of Hexaaqua-1,3-diammoniumpropane Cobalt(II) Nitrate, $\mathrm{Co}\left(\mathrm{H}_{2} \mathrm{O}\right)_{6}\left[\mathrm{C}_{3} \mathrm{H}_{12} \mathrm{~N}_{2}\right]\left(\mathrm{NO}_{3}\right)_{4}$
}

\author{
M. L. MRAD, C. BEN NASR* and M. RZAIGUI \\ Laboratoire de Chimie des Matériaux, \\ Faculté des Sciences de Bizerte, 7021 - Zarzouna - Bizerte, Tunisie. \\ cherif.bennasr@fsb.rnu.tn
}

Received 28 October 2009; Accepted 20 December 2009

\begin{abstract}
Chemical preparation and $\mathrm{x}$-ray characterization of a new compound hexaaqua-1,3-diammoniumpropane cobalt(II) nitrate, $\mathrm{Co}\left(\mathrm{H}_{2} \mathrm{O}\right)_{6}$ $\left[\mathrm{C}_{3} \mathrm{H}_{12} \mathrm{~N}_{2}\right]\left(\mathrm{NO}_{3}\right)_{4}$ are reported. This mixed organo-mineral compound crystallizes in the orthorhombic system with $\mathrm{Cmcm}$ space group. The unit cell dimensions are: $\mathrm{a}=10.795(7), \mathrm{b}=11.969(4), \mathrm{c}=14.685(5) \AA, \mathrm{Z}=4$ and $\mathrm{V}=1897.5(12) \AA^{3}$. The structure was solved using the direct method and refined to reliability R-factor of 0.036 using 2554 independent reflections. In this atomic arrangement the different species built a three-dimensional network.
\end{abstract}

Keywords: Complex, X-ray crystal structure, IR spectroscopy.

\section{Introduction}

Organic inorganic compounds constitute a vast family of hybrid materials of considerable technological importance. Indeed, due to the nature (molecular, ionic, hydrogen bonding, etc...) of organic and inorganic components, many combinations may be achieved to elaborate suitable materials, so as to exhibit some interesting crystal structure and some special properties in several areas, such as nonlinear optical (NLO), magnetism, luminescence, photography and drug delivery, etc ${ }^{1-11}$. Moreover, hydrogen bonding is of intense interest because of their widespread occurrence in biological systems. So, it is very helpful to search simple molecules allowing to understanding the configuration and the function of some complex macromolecules. The hybrid compounds are rich in $H$-bonds and they could be used to this effect because of their potential importance in constructing sophisticated assemblies from discrete ionic or molecular building blocks due to its strength and directionality ${ }^{12}$. In order to enrich the varieties in such kinds of hybrid materials and to investigate the influence of hydrogen bonds on the structural features, we have synthesized a new compound, hexaaqua-1,3-diammoniumpropane cobalt(II) nitrate, $\mathrm{Co}\left(\mathrm{H}_{2} \mathrm{O}\right)_{6}\left[\mathrm{C}_{3} \mathrm{H}_{12} \mathrm{~N}_{2}\right]\left(\mathrm{NO}_{3}\right)_{4}$. 


\section{Experimental}

The title compound was prepared by the reaction of cobalt nitrate, propanediamine and phosphoric acid in ethanol/water $(1: 1, \mathrm{v} / \mathrm{v})$. The resulting mixture was heated to boiling point an stirred two hours. After three days single crystals were obtained by slow evaporation from aqueous solution at room temperature.

Crystals of the title compound were prepared according to the following chemical reaction:

$$
\left[\mathrm{C}_{3} \mathrm{H}_{10} \mathrm{~N}_{2}\right]+2 \mathrm{H}_{3} \mathrm{PO}_{4}+\mathrm{Co}\left(\mathrm{NO}_{3}\right)_{2} \longrightarrow \mathrm{Co}\left(\mathrm{H}_{2} \mathrm{O}\right)_{6}\left[\mathrm{C}_{3} \mathrm{H}_{12} \mathrm{~N}_{2}\right]\left(\mathrm{NO}_{3}\right)_{4}
$$

The chemical formula was determined during the $\mathrm{x}$-ray crystal structure analysis. A single crystal with the dimension of $(0.4 \times 0.3 \times 0.2) \mathrm{mm}$ was chosen for $\mathrm{x}$-ray diffraction studies. The measurements were made on an Enraf-Nonius CAD 4 diffractometer. The structure was solved by direct methods using the SIR $92^{13}$ program and refined by full matrix least-squares techniques based on $\mathrm{F}$ using teXan ${ }^{14}$. The hydrogen atoms were not refined and all non-hydrogen atoms were refined anisotropically. The crystal and experimental data are given in Table 1.

The infrared spectrum was recorded in the range $4000-400 \mathrm{~cm}^{-1}$ with a "Perkin-Elmer FTIR1000 " spectrophotometer using a sample dispersed in spectroscopically pure $\mathrm{KBr}$ pellets.

Table 1. Crystal data, experimental parameters used for the intensity data collection, strategy and final results of the structure determination $\mathrm{Co}\left(\mathrm{H}_{2} \mathrm{O}\right)_{6}\left[\mathrm{C}_{3} \mathrm{H}_{12} \mathrm{~N}_{2}\right]\left(\mathrm{NO}_{3}\right)_{4}$.

\begin{tabular}{|c|c|}
\hline .Empirical formula & $\mathrm{C}_{3} \mathrm{H}_{24} \mathrm{~N}_{6} \mathrm{CoO}_{18}$ \\
\hline Formula weight & 491.19 \\
\hline $\mathrm{T}(\mathrm{K})$ & 293 \\
\hline Wavelength $(\AA)$ & 0.7107 \\
\hline Crystal system & Orthorhombic \\
\hline Space group & $\mathrm{Cmcm}$ \\
\hline $\mathrm{a}(\AA)$ & $10.795(7)$ \\
\hline $\mathrm{b}(\AA)$ & $11.969(4)$ \\
\hline c $(\AA)$ & $14.685(5)$ \\
\hline$V\left(\AA^{3}\right)$ & $1897.5(12)$ \\
\hline $\mathrm{Z}$ & 4 \\
\hline $\mathrm{D}_{\text {calc }}, \mathrm{g} \mathrm{cm}^{-3}$ & 1.719 \\
\hline$\mu\left(\mathrm{MoK}_{\alpha}\right), \mathrm{mm}^{-1}$ & 1.004 \\
\hline $\mathrm{F}(000)$ & 1020 \\
\hline $\begin{array}{l}\text { Reflections } \\
\text { collected/unique, } \mathrm{R}_{\text {int }}\end{array}$ & $2554 / 2554,(0.0003)$ \\
\hline Observed data $(I>3 \sigma(I))$ & 1597 \\
\hline No. of variables & 78 \\
\hline Goodness-of-fit & 1.760 \\
\hline $\mathrm{R}$ & 0.034 \\
\hline $\mathrm{R}_{\mathrm{w}}$ & 0.052 \\
\hline
\end{tabular}

\section{Results and Discussion}

The $\mathrm{C} 1$ atom is resolved into two sites and occupies two atomic positions, with occupancy factor 0.5 (Figure 1). The asymmetric unit of crystal structure, depicted in ORTEP drawing (Figure 1), corresponds to the formula unit $\left[\mathrm{Co}\left(\mathrm{H}_{2} \mathrm{O}\right)_{6}\right]^{2+}$. $\left[\mathrm{C}_{3} \mathrm{H}_{12} \mathrm{~N}_{2}\right]^{2+}$. $4\left[\mathrm{NO}_{3}\right]^{-}$. The main feature of this atomic arrangement is the existence of inorganic layers spreading around (a,c) plane (Figure 2). Inside layers $\left(\mathrm{NO}_{3}\right)^{-}$anion is linked to $\mathrm{Co}\left(\mathrm{H}_{2} \mathrm{O}\right)_{6}$ polyhedra through $\mathrm{O}-\mathrm{H} . . . \mathrm{O}$ bonding (Figure 3 ). The $\mathrm{H}$... O bond lengths are in the ranges of $1.92-2.24 \AA$. The organic cation is located between this layers and building the three-dimensional network by N-H...O hydrogen bonds (Figure 4). 


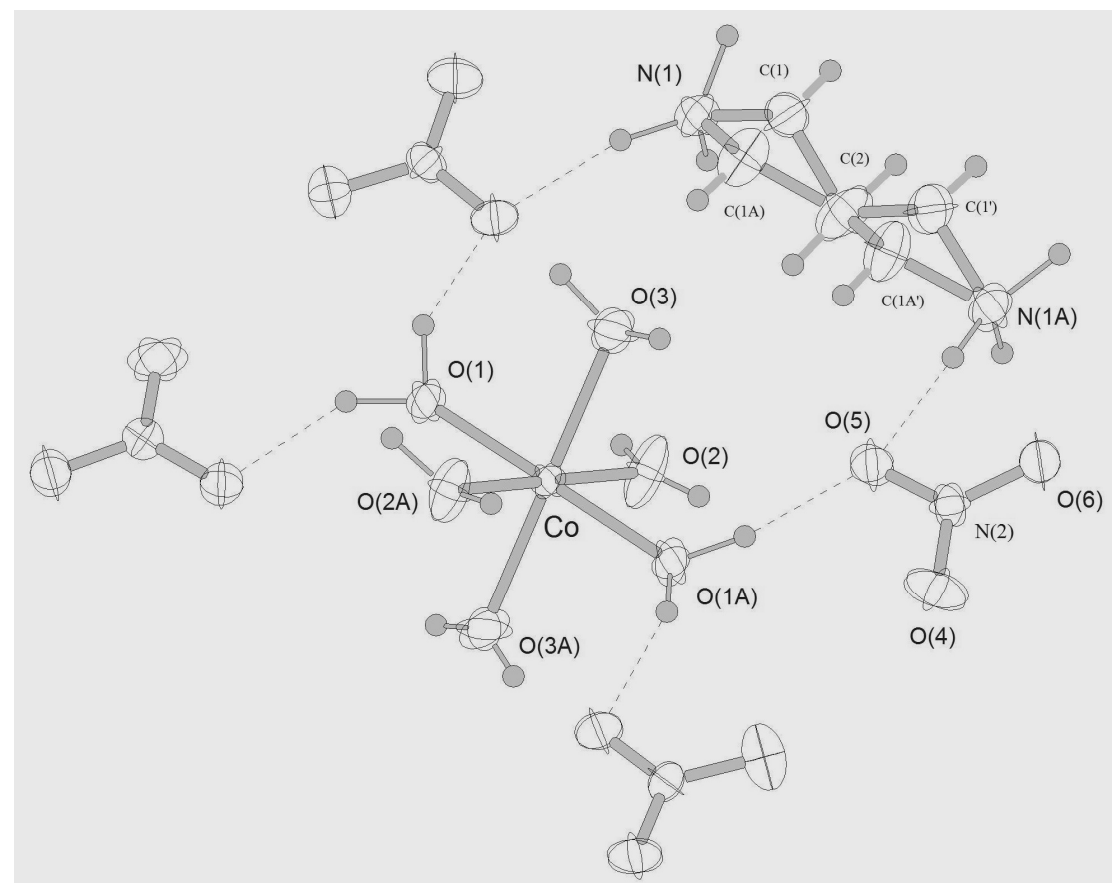

Figure 1. Asymmetric unit of $\mathrm{Co}\left(\mathrm{H}_{2} \mathrm{O}\right)_{6}\left[\mathrm{C}_{3} \mathrm{H}_{12} \mathrm{~N}_{2}\right]\left(\mathrm{NO}_{3}\right)_{4}$ with atom labels and $50 \%$ probability displacement ellipsoids for non- $\mathrm{H}$ atoms.

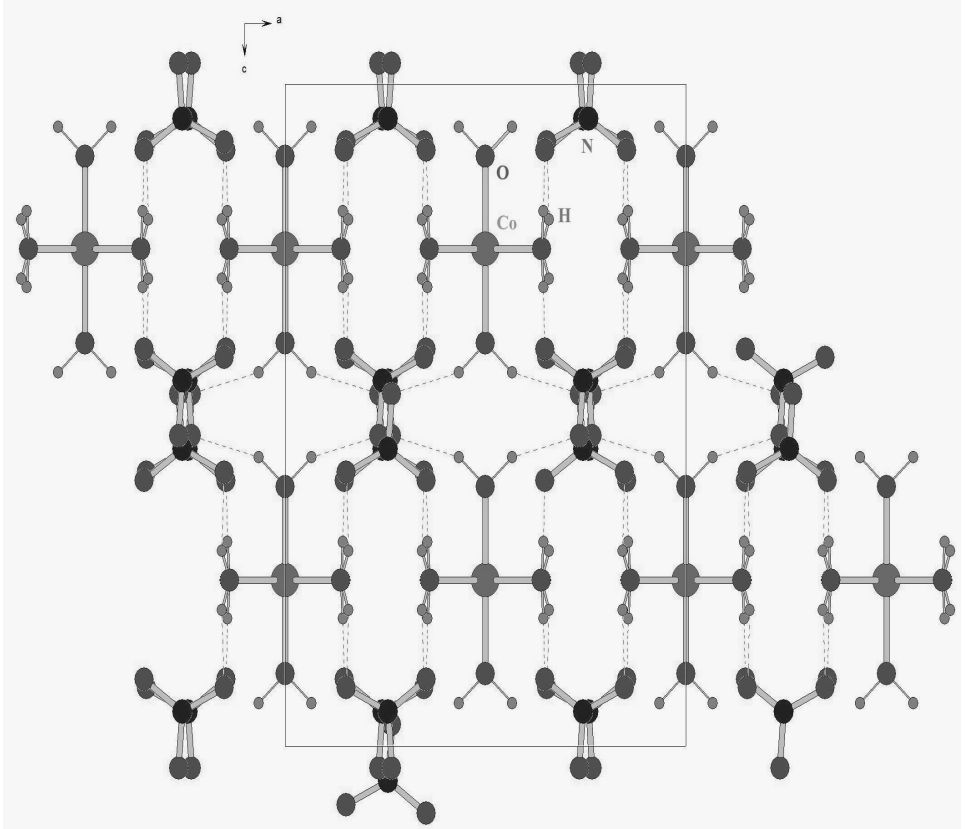

Figure 2. Projection of the structure of $\mathrm{Co}\left(\mathrm{H}_{2} \mathrm{O}\right)_{6}\left[\mathrm{C}_{3} \mathrm{H}_{12} \mathrm{~N}_{2}\right]\left(\mathrm{NO}_{3}\right)_{4}$ along the a axis. hydrogen bonds are denoted by dotted lines. 


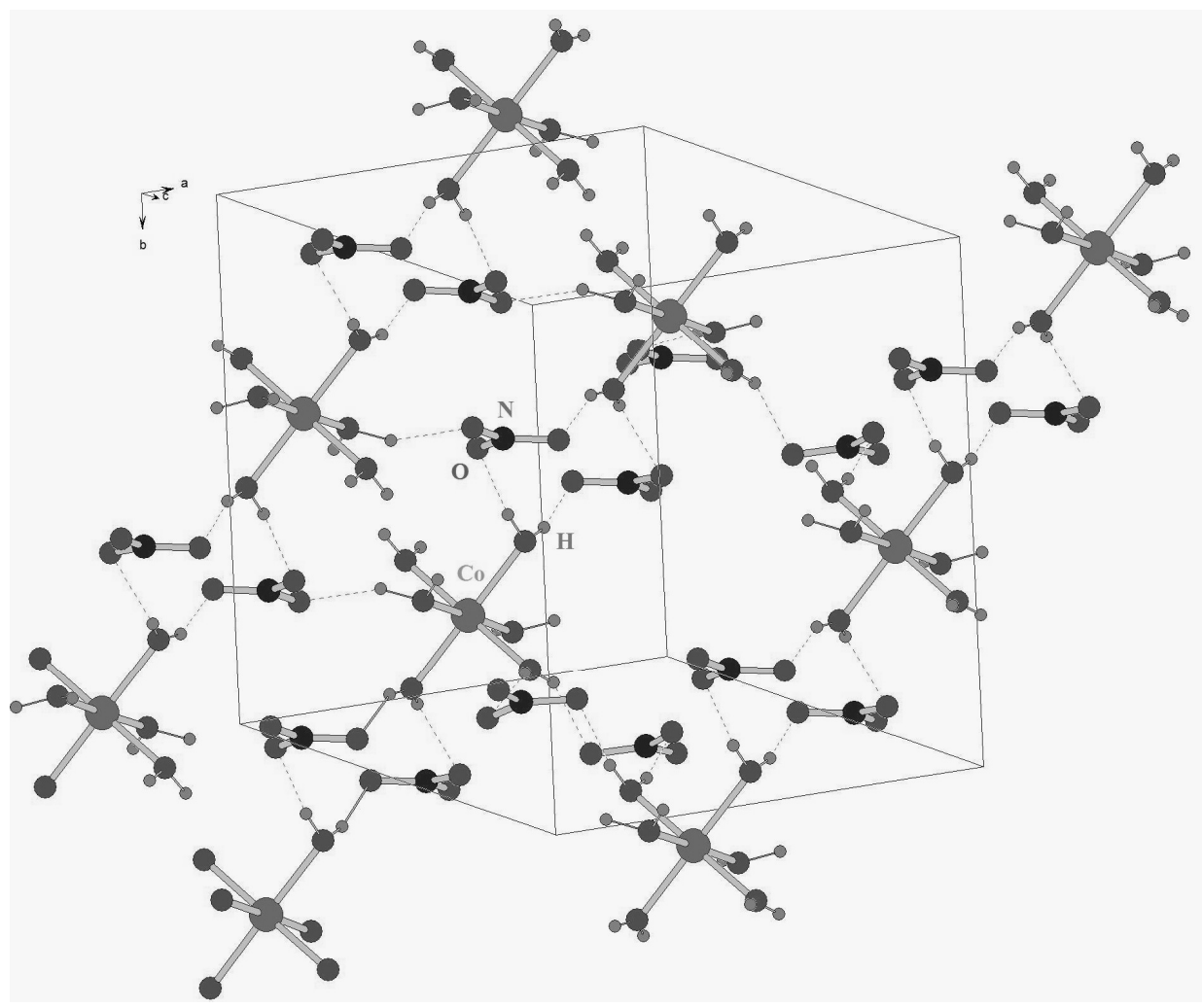

Figure 3. The layer of $\mathrm{Co}\left(\mathrm{H}_{2} \mathrm{O}\right)_{6}\left[\mathrm{C}_{3} \mathrm{H}_{12} \mathrm{~N}_{2}\right]\left(\mathrm{NO}_{3}\right)_{4}$ in perspective projection.

The various chemical species manifest mainly electrostatic interactions and hydrogen bonds. In this arrangement, the cobalt atom which has the oxidation state $\left(+2, \mathrm{~d}^{7}\right)$ coordinated by six water molecules to form $\mathrm{Co}\left(\mathrm{H}_{2} \mathrm{O}\right)_{6}$ octahedral. The average values of the $\mathrm{Co}-\mathrm{O}$ distances and $\mathrm{O}-\mathrm{Co}-\mathrm{O}$ angles are $2.085 \AA$ and $89.92^{\circ}$ respectively. These values, indicating a slightly distorted octahedron around the cobalt. The nearest Co...Co separation is $8.059 \AA$. All these values are consistent with those found in $\left[\mathrm{Co}\left(\mathrm{H}_{2} \mathrm{O}\right)_{4} \mathrm{pyr}\right]\left(\mathrm{NO}_{3}\right)_{2}\left(\mathrm{H}_{2} \mathrm{O}\right)_{2}{ }^{15}$. The electric neutrality of the total complex is ensured by the $\left(\mathrm{NO}_{3}\right)^{-}$anions. All the N-O bonds of the nitrate groups are in the range 1.233(2) - 1.247(2) $\AA$ and the angles vary between $119.2(1)$ and $121.5(2)^{\circ}$.

The diammonium propane chain lies across a crystallographic inversion centre and hence the asymmetric unit contains one nitrate anion, one-half $\mathrm{Co}\left(\mathrm{H}_{2} \mathrm{O}\right)_{6}$ octahedral and one-half of propane diammonium cation. The hydrocarbon chain is also not extended as in common in long chained hydrocarbons but shows significant folding and deviation from planarity. This is clearly evident from the torsion angle along $\mathrm{N}(1)-\mathrm{C}(1)-\mathrm{C}(2)-\mathrm{C}(1 \mathrm{~A})$ bonds $\left(179.5^{\circ}\right)$.

Regarding the organic cation arrangement, the protonated propandiammonium molecule participates to the three dimensional cohesion and neutralizes the negative charge of the anionic part. The examination of the organic cation shows that the values of the N-C, C-C distances and N-C-C, C-C-C angles range from 1.429 (4) to $1.446(4)$ and 117.7 to $119.2^{\circ}$, respectively. These values are similar to those obtained in other organic materials containing the same organic groups ${ }^{16}$. 


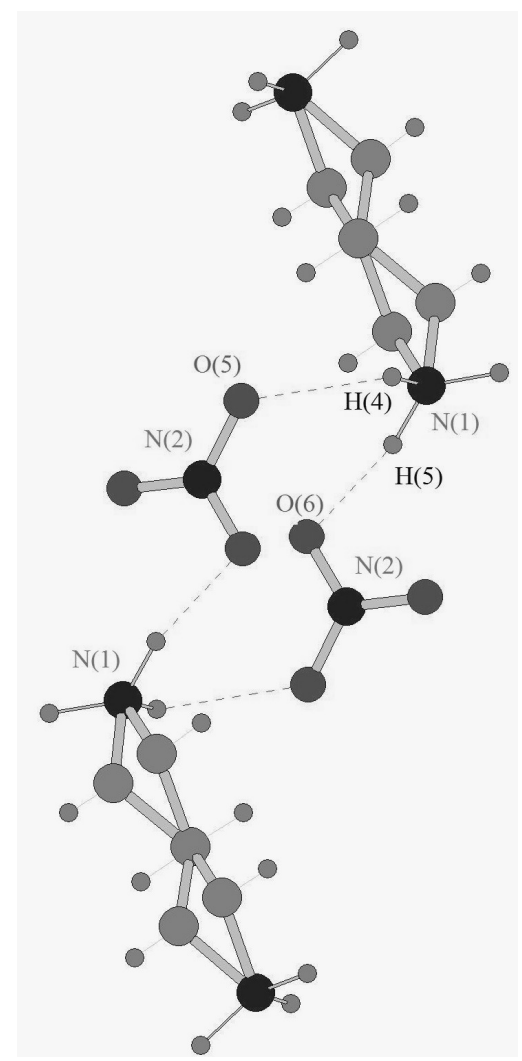

Figure 4. The $\mathrm{N}-\mathrm{H}$... O hydrogen-bonded in $\mathrm{Co}\left(\mathrm{H}_{2} \mathrm{O}\right)_{6}\left[\mathrm{C}_{3} \mathrm{H}_{12} \mathrm{~N}_{2}\right]\left(\mathrm{NO}_{3}\right)_{4}$.

The IR spectrum of crystalline $\mathrm{Co}\left(\mathrm{H}_{2} \mathrm{O}\right)_{6}\left[\mathrm{C}_{3} \mathrm{H}_{12} \mathrm{~N}_{2}\right]\left(\mathrm{NO}_{3}\right)_{4}$ is shown in Figure 5. To assign the IR bands to vibration modes, we have examined the modes and frequencies observed in similar compounds ${ }^{17,18}$.

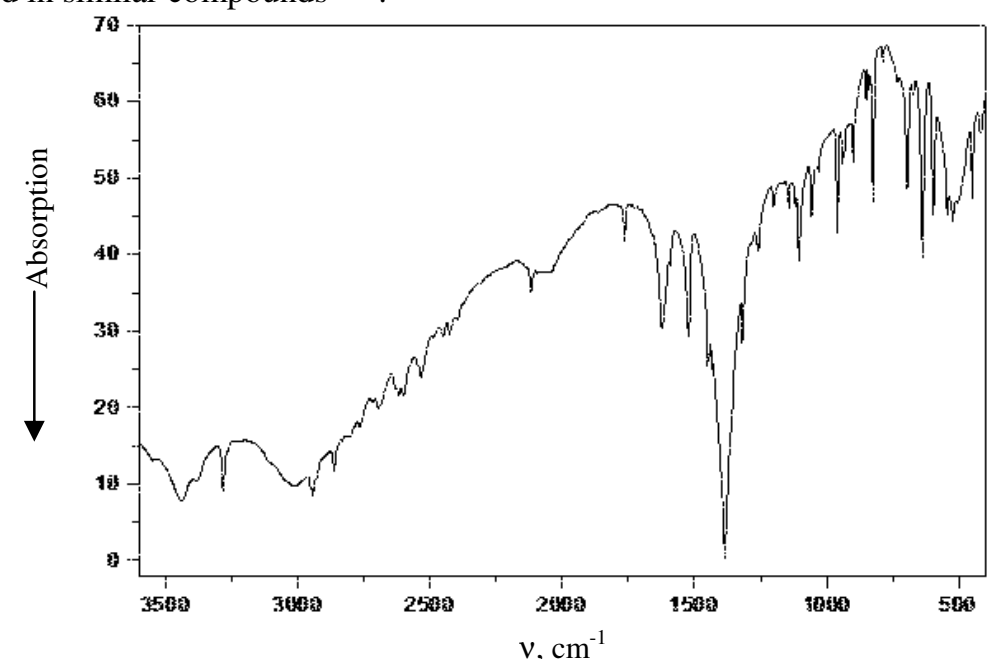

Figure 5. IR absorption spectrum of $\mathrm{Co}\left(\mathrm{H}_{2} \mathrm{O}\right)_{6}\left[\mathrm{C}_{3} \mathrm{H}_{12} \mathrm{~N}_{2}\right]\left(\mathrm{NO}_{3}\right)_{4}$. 
Table 2. Final atomic coordinates and $\mathrm{B}_{\mathrm{eq}} .\left(\AA^{2}\right)$ in $\mathrm{Co}\left(\mathrm{H}_{2} \mathrm{O}\right)_{6}\left[\mathrm{C}_{3} \mathrm{H}_{12} \mathrm{~N}_{2}\right]\left(\mathrm{NO}_{3}\right)_{4}$.

\begin{tabular}{cccccc}
\hline Atoms & $\mathrm{x}(\sigma)$ & $\mathrm{y}(\sigma)$ & $\mathrm{z}(\sigma)$ & $\mathrm{B}_{\mathrm{eq}}$ & Occupancy \\
\hline $\mathrm{Co}(1)$ & 0.0000 & $0.36242(2)$ & 0.2500 & $0.02485(11)$ & 0.5 \\
$\mathrm{O}(1)$ & $0.14018(11)$ & $0.48398(10)$ & 0.2500 & $0.0473(3)$ & \\
$\mathrm{O}(2)$ & $0.13856(13)$ & $0.24133(11)$ & 0.2500 & $0.0531(3)$ & \\
$\mathrm{O}(3)$ & 0.0000 & $0.36078(9)$ & $0.10872(8)$ & $0.0376(3)$ & 0.5 \\
$\mathrm{O}(4)$ & $0.15319(9)$ & $0.11431(7)$ & $0.08694(7)$ & $0.0452(2)$ & \\
$\mathrm{O}(5)$ & $0.35245(11)$ & $0.12676(6)$ & $0.09953(8)$ & $0.0498(3)$ & \\
$\mathrm{O}(6)$ & $0.26634(8)$ & $0.12664(6)$ & $-0.03240(7)$ & $0.0391(2)$ & \multirow{2}{*}{0.5} \\
$\mathrm{~N}(1)$ & 0.5000 & $0.33612(12)$ & $0.08115(10)$ & $0.0398(3)$ & \\
$\mathrm{N}(2)$ & $0.25685(8)$ & $0.12255(5)$ & $0.05203(7)$ & $0.0297(3)$ & \\
$\mathrm{C}(1)$ & $0.4634(2)$ & $0.3859(2)$ & $0.1667(2)$ & $0.0435(7)$ & \\
$\mathrm{C}(2)$ & 0.5000 & $0.3336(2)$ & 0.2500 & $0.0537(7)$ & \\
$\mathrm{H}(1)$ & 0.1444 & 0.5212 & 0.1926 & 0.023 & \\
$\mathrm{H}(2)$ & 0.1586 & 0.2232 & 0.2053 & 0.023 & \\
$\mathrm{H}(3)$ & 0.0605 & 0.3791 & 0.0607 & 0.023 & 0.5 \\
$\mathrm{H}(4)$ & 0.5000 & 0.2571 & 0.0798 & 0.023 & \\
$\mathrm{H}(5)$ & 0.4079 & 0.3598 & 0.0601 & 0.023 & \\
$\mathrm{H}(6)$ & 0.5796 & 0.3668 & 0.2500 & 0.023 & 0.5 \\
$\mathrm{H}(7)$ & 0.3862 & 0.3849 & 0.1660 & 0.023 & \\
\hline Standard deviations are given in parentheses. $B_{\text {eq }}=4 / 3 \sum_{i} \sum_{j} \beta_{i j}$ & $\mathbf{a}_{\mathrm{i}} \cdot \mathbf{a}_{\mathrm{j}} \cdot$
\end{tabular}

Table 3. Hydrogen-bond geometry $\left(\AA{ }^{\circ}\right)$ in $\mathrm{Co}\left(\mathrm{H}_{2} \mathrm{O}\right)_{6}\left[\mathrm{C}_{3} \mathrm{H}_{12} \mathrm{~N}_{2}\right]\left(\mathrm{NO}_{3}\right)_{4}$.

\begin{tabular}{ccccc}
\hline $\mathrm{D}-\mathrm{H} \ldots \mathrm{A}$ & $\mathrm{D}-\mathrm{H}(\AA)$ & $\mathrm{H} \ldots \mathrm{A}(\AA)$ & $\mathrm{D}-\mathrm{A}(\AA)$ & $\mathrm{D}-\mathrm{H} \ldots \mathrm{A}\left({ }^{\circ}\right)$ \\
\hline $\mathrm{O}(1)-\mathrm{H}(1) \ldots \mathrm{O}(5)$ & 0.95 & 1.86 & $2.795(2)$ & 165.1 \\
$\mathrm{O}(2)-\mathrm{H}(2) \ldots \mathrm{O}(4)$ & 0.72 & 2.17 & $2.841(2)$ & 153.7 \\
$\mathrm{O}(3)-\mathrm{H}(3) \ldots \mathrm{O}(6)$ & 0.99 & 1.92 & $2.764(2)$ & 142.5 \\
$\mathrm{~N}(1)-\mathrm{H}(4) \ldots \mathrm{O}(5)$ & 0.94 & 2.24 & $2.983(2)$ & 133.7 \\
$\mathrm{~N}(1)-\mathrm{H}(5) \ldots \mathrm{O}(6)$ & 1.07 & 1.92 & $2.994(2)$ & 168.5 \\
\hline
\end{tabular}

The high-frequency region broad bands, between $3600-2300 \mathrm{~cm}^{-1}$, are attributed to the stretching vibrations of organic and hydroxyl groups $v(\mathrm{C}-\mathrm{H}), v(\mathrm{~N}-\mathrm{H})$ and $v(\mathrm{O}-\mathrm{H})$ of $\mathrm{H}_{2} \mathrm{O}$ molecules.

The vibrations between 1650 and $1200 \mathrm{~cm}^{-1}$ are assigned to bending and stretching modes $\delta(\mathrm{N}-\mathrm{H}), v(\mathrm{C}-\mathrm{C})$ and $v(\mathrm{C}-\mathrm{N})^{19,20}$. The bands vibrations between 1000 and $750 \mathrm{~cm}^{-1}$ are attributed to out of plane bending modes $\gamma(\mathrm{C}-\mathrm{H}), \gamma(\mathrm{C}-\mathrm{C})$ and $\gamma(\mathrm{C}-\mathrm{N})^{21}$.

\section{Supplementary material}

Crystallographic data for the structural analysis have been deposited at the Cambridge Crystallographic Data Centre, CCDC No 700770 Copies of this information may be obtained free of charge from The Director, CCDC, 12 Union Road, Cambridge, CB2 IEZ, UK

\section{Acknowledgments}

We would like to acknowledge the support provided by the Secretary of State for Scientific Research and Technology of TUNISIA. 


\section{References}

1. Wang J T, Savinell R F, Wainright J, Litt M and Yu H, Electrochim Acta, 1996, 41, 193.

2. Coombs N, Khuehniani D, Silver S, Ozin G A, Shen G C, Sokolov I and Yang H, J Chem Soc Dalton Trans., 1997, 21, 3941.

3. Mitzi D B, J Chem Soc Dalton Trans., 2001, 1.

4. Mitzi D B, Prog Inorg Chem., 1999, 48, 1.

5. Qin J, Dai C, Liu D, Chen C, Wu B, Yang C and Zhan C, Coord Chem Rev., 1999, 188, 23.

6. Jiang M and Fang Q, Adv Mater., 1999, 11, 1147.

7. Ogawa M and Kuroda K, Chem Rev., 1995, 95, 399.

8. Pécaut J, Le Fur Y, Levy J P and Masse R, J Mater Chem., 1993, 3, 333.

9. Lacroix P G, Chem Mater., 2001, 13, 3495.

10. Lacroix P G, Clément R, Nakatani K, Delaire J A, Zyss J and Ledoux I, Science, 1994, 263, 658.

11. Bringley J F and Rajeswaran M, Acta Cryst., 2006, E62, m1304.

12. Steiner T, Angew Chem Int Ed., 2002, 41, 48.

13. Altomare A, Cascrano M, Giacovazzo C and Guzgliardi, J Appl Cryst., 1993, 26, 343.

14. TeXan for Windows version 1.03, Molecular Structure Corporation, Single Crystal Structure Analysis Software, Version 1.03, MSC, 3200 Research Forest Drive, The Woodlands, TX, USA, 1997.

15. Travis Holman K, Hammud H, Isbar S and Tabbal M, Polyhedron, 2005, 24, 221.

16. Van blerk C and Kruger G J, Acta Cryst., 2009, E65, 1008.

17. Souisssi S, Smirani W, Ben Nasr C and Rzaigui M, Phosphorus Sulfur Silicon, 2007, 182, 1731.

18. Bhattacharaya R, Ray M S, Dey R, Righi L, Bocelli G and Ghosh A, Polyhedron, 2002, 21, 2561.

19. Kaabi K, Rayes A, Ben Nasr C and Rzaigui M and Lefebvre F, Mater Res Bull., 2003, 38, 741 .

20. Oueslati A, Ben Nasr C, Durif A and Lefebvre F, Mater Res Bull., 2005, 40, 970.

21. Oueslati A, Rayes A, Ben Nasr C and Lefebvre F, Mater Res Bull., 2005, 40, 1680. 


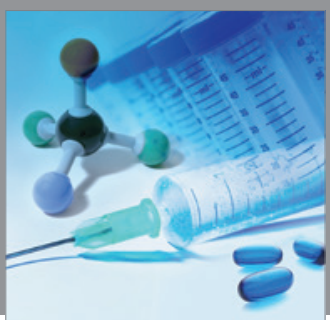

International Journal of

Medicinal Chemistry

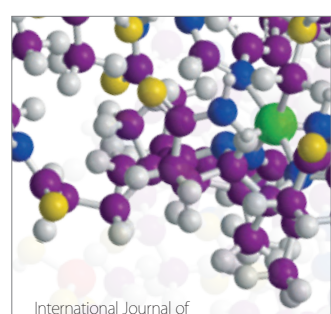

Carbohydrate Chemistry

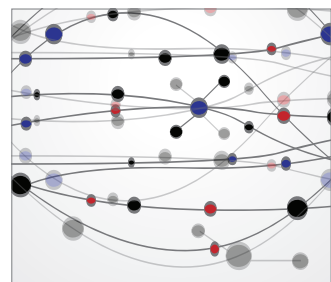

The Scientific World Journal
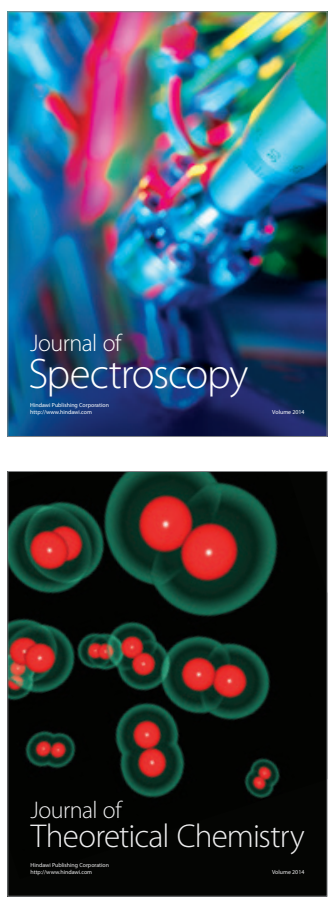
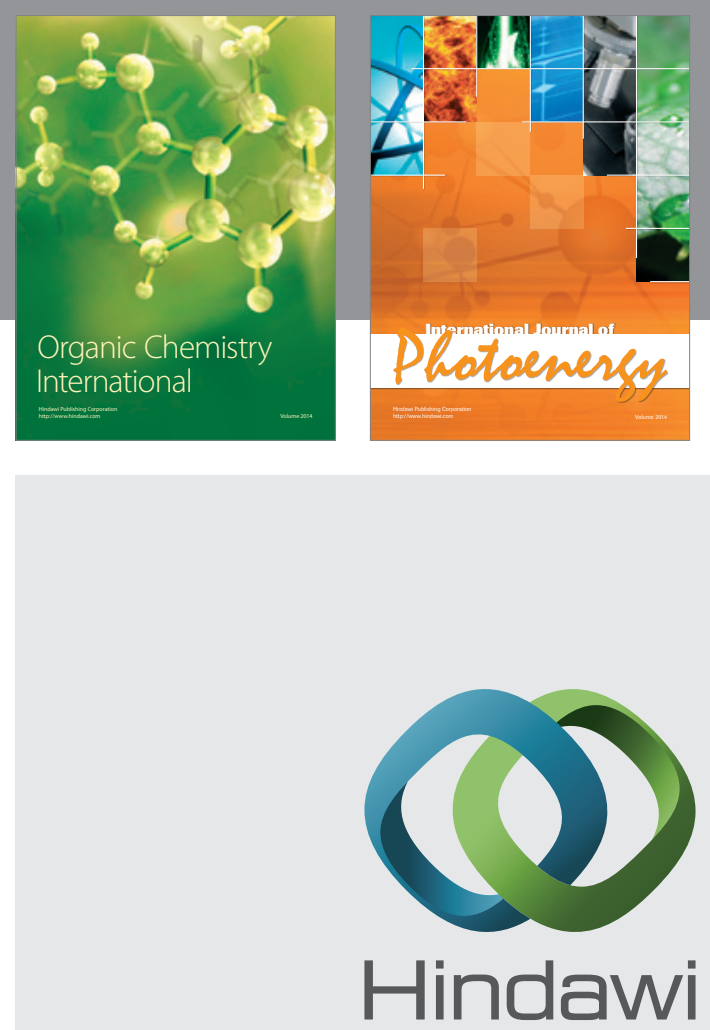

Submit your manuscripts at

http://www.hindawi.com
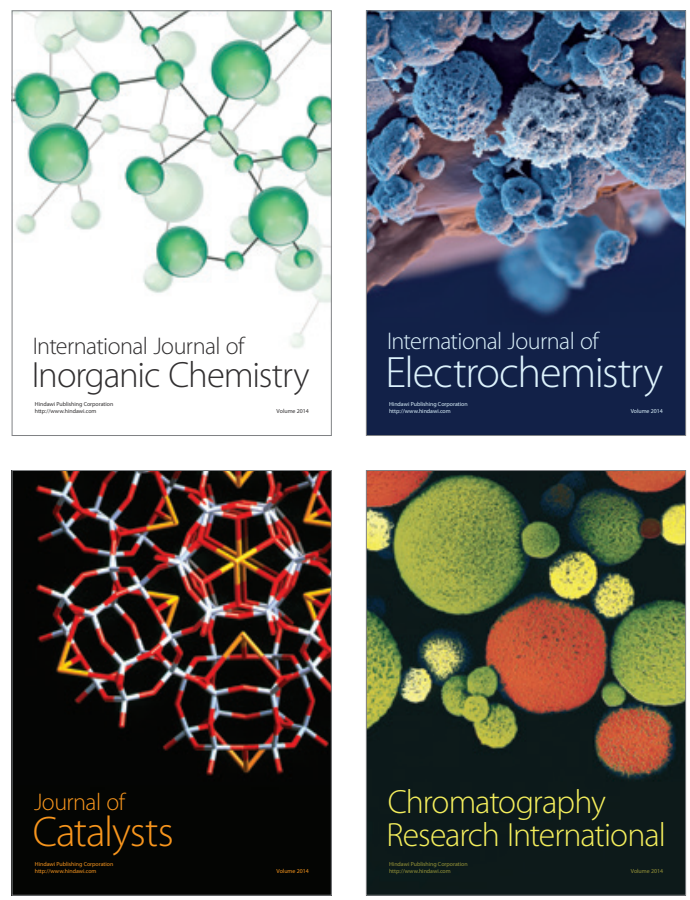
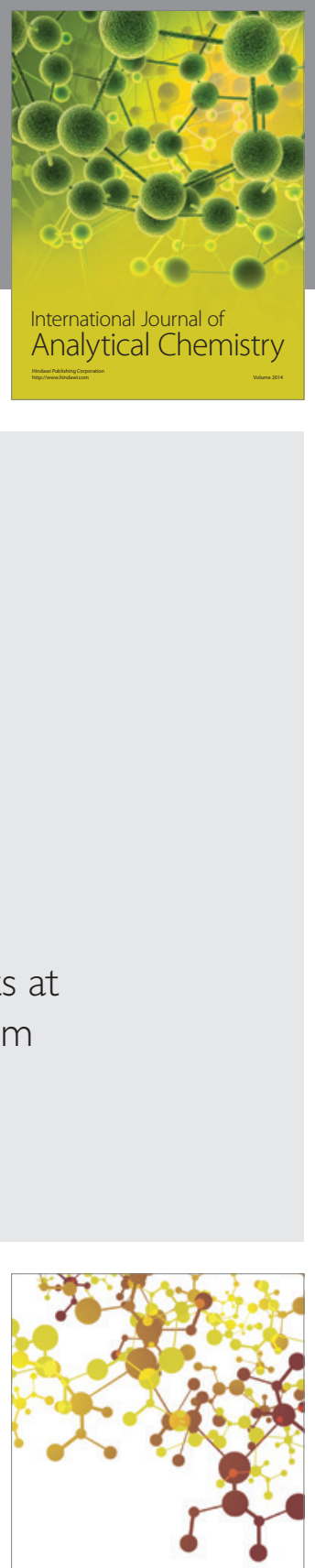

Journal of

Applied Chemistry
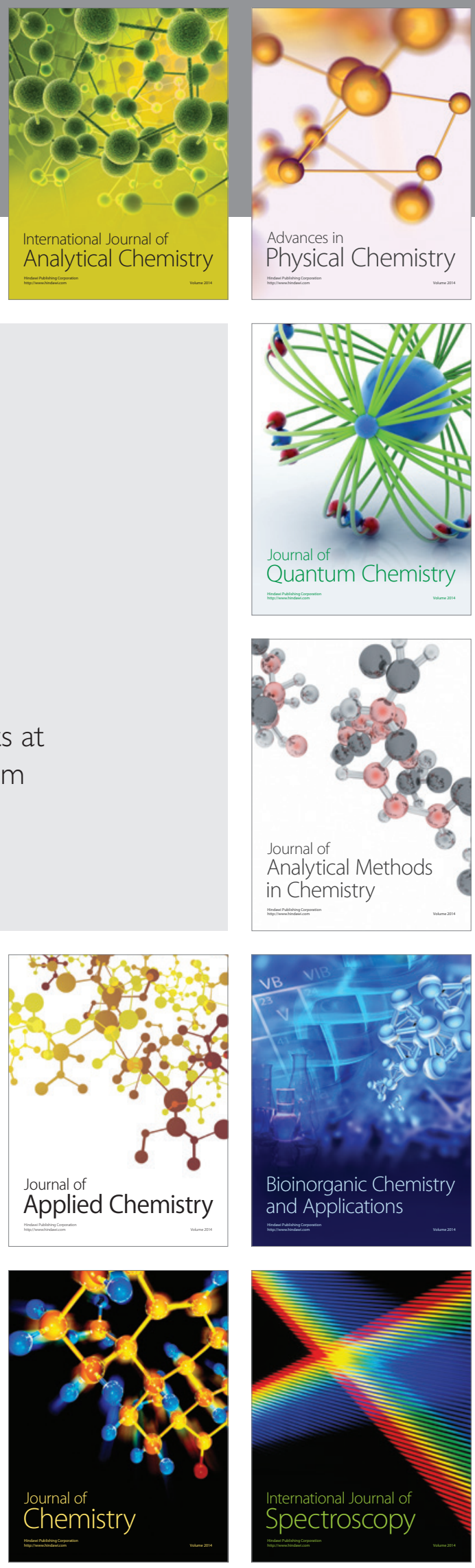